\title{
Organizational wrongdoing in courts of accounts
}

\author{
André Feliciano Lino ${ }^{1}$ \\ André Carlos Busanelli de Aquino ${ }^{2}$ \\ 1 Universidade Federal do Pará / Faculdade de Ciências Contábeis, Belém / PA - Brazil \\ ${ }^{2}$ Universidade de São Paulo / Faculdade de Economia, Administração e Contabilidade de Ribeirão Preto, Ribeirão Preto / SP - Brazil
}

\begin{abstract}
Historically, the Brazilian Courts of Accounts have been questioned over the frequent misconduct of magistrates. This article analyzed how organizational wrongdoing is sustained and preserved by magistrates, their cabinet members, audit directors and technical body members, who hold influence and power in this type of organization typically permeated by multiple incompatible and conflicting institutional logics. The case of the Rio de Janeiro State Court of Accounts was analyzed to discover the socially illegitimate practices widely adopted in the organization and which recently became public. A qualitative approach was used based on interviews (with auditors and magistrates) and public documents. The analysis indicates that an elite-patrimonial institutional logic was operating at the Rio de Janeiro State Court of Accounts, which induced organizational wrongdoing, based on the use of episodic and systemic power strategies and reciprocity norms. Finally, the findings point out that supportive wrongdoing is seen in the hierarchy, operating under the influence of systemic power in general, applied to sustain the embryonic strategies of wrongdoing. Keywords: organizational wrongdoing; courts of accounts; institutional logic; corruption.
\end{abstract}

\section{Práticas não adequadas nos tribunais de contas}

Os tribunais de contas brasileiros como organizações de auditoria governamental têm sido historicamente questionados pela continua revelação de práticas socialmente contestadas atribuídas aos conselheiros. Este artigo analisa a manutenção dessas más práticas (organizational wrongdoing), sustentadas e apoiadas pela atuação de conselheiros, assessores, diretores de auditoria e apoiadores do escalão técnico, os quais detém maior influência e poder em uma organização tipicamente permeada por lógicas institucionais incompatíveis e conflitantes. Utilizouse o caso do Tribunal de Contas do Estado do Rio de Janeiro para analisar as práticas ilegítimas largamente utilizadas que se tornaram públicas recentemente. $\mathrm{O}$ caso foi analisado em uma abordagem qualitativa, a partir de entrevistas (com auditores e conselheiros da organização) trianguladas com documentos públicos. A análise conclui que a lógica institucional elite-patrimonialista que opera naquela organização induziu o amplo uso de más práticas naquele tribunal, as quais foram legitimadas por estratégias de poder (episódico e sistêmico) e por trocas recíprocas em todos os níveis organizacionais. Ainda, a análise identificou más práticas de suporte que surgem ao longo da hierarquia, operadas sob influência de poder sistêmico em geral, que são desdobramentos de estratégias para sustentar as más práticas embrionárias.

Palavras-chave: lógicas institucionais; práticas não adequadas; tribunais de contas; corrupção.

\section{Prácticas inadecuadas en los tribunales de cuentas}

Históricamente, los tribunales de cuentas brasileños como organizaciones de auditoría del gobierno han sido cuestionados por la divulgación continua de prácticas socialmente censuradas atribuidas a los consejeros. Este artículo analiza el mantenimiento de esas malas prácticas (organizational wrongdoing), sostenidas y respaldadas por las acciones de consejeros, asesores, directores de auditoría y miembros del cuerpo técnico de auditoría, que tienen una mayor influencia y poder en una organización típicamente impregnada de lógicas institucionales incompatibles y conflictivas. Se utilizó el caso del Tribunal de Cuentas del Estado de Río de Janeiro para analizar las prácticas ilegítimas ampliamente utilizadas que recientemente se han hecho públicas. El caso fue analizado desde un enfoque cualitativo, basado en entrevistas (con auditores y consejeros de la organización) trianguladas con documentos públicos. El análisis concluye que la lógica institucional de élite patrimonialista que opera en esa organización indujo al uso generalizado de prácticas inapropiadas en esa corte, que fueron legitimadas por estrategias de poder (episódico y sistémico) y por intercambios recíprocos en todos los niveles organizacionales. Aun, el análisis identificó malas prácticas de soporte que surgen a lo largo de la jerarquía, operadas bajo la influencia del poder sistémico en general, que son estrategias que se desarrollan para sostener malas prácticas embrionarias. Palabra clave: lógica institucional; prácticas inapropiadas; tribunales de cuentas; corrupción. 


\section{INTRODUCTION}

Recent scandals attracted the attention of researchers and civil society to several cases of organizational wrongdoing. Such illegitimate and inappropriate practices occur both at the public and at the private sectors and typically involve multiple organizations. Examples are the benefits in TV rights' contracts on competitions of the Fédération Internationale de Football Association (FIFA) (Sugden \& Tomlinson, 2017), Uber's alleged buying of a hacker's silence to hide leaking customer data (CBS, 2019). In Brazil, the operations of the Federal Police investigated the possible adulteration of products by the Brazilian meat processing company JBS (Operação Carne Fraca), or the conflict of interests in the Brazilian Conselho de Administração de Recursos Fiscais (CARF) responsible for adjudicating disputes over federal income tax (Operação Zelotes) (Arantes, Gusmão, \& Costa, 2019). Furthermore, the Federal Police also uncovered corruption schemes under the well-known operation Lava Jato (Arantes, Gusmão, \& Costa, 2019), even though there were critics to the practices employed by the task force throughout the investigation and judgment phases (Intercept Brasil, 2019).

All the mentioned organizational wrongdoing commonly has violated laws, professional codes, or ethical principles by actors pursuing either individual or organizational goals. Recently, the literature on organizational wrongdoing or organizational misconduct started to explore similar cases (Greve, Palmer, \& Pozner, 2010; Palmer, 2017; Palmer, Smith-Crowe, \& Greenwood, 2016). This literature has considerably advanced the discussion of the determinants of wrongdoing at the individual level of analysis and the consequences for the organization as a whole (Palmer, 2017; Palmer et al., 2016). The organizational wrongdoing occurrences are no longer considered as one-off events, but as a persistent phenomenon associated to similar structures, artifacts, and processes designed to generate efficiency gains, such as formal hierarchical power structures (Palmer, 2013). The Brazilian Courts of Accounts are an example of an organization that is frequently associated with organization wrongdoing. The seminal article by Loureiro, Teixeira, and Moraes (2009) points out the connections between politicians and high-ranked positions (i.e., Magistrates) within the Courts of Accounts. More recently, Teixeira (2017) brought several pieces of evidence of wrongdoing performed by Courts' Magistrates, such as conspiracy, active corruption, bribes, kickbacks, and support to bid rigging.

Organizational practices - adequate or not - are intertwined and are inseparable from the organizational process flow, routines, norms, and beliefs (Jarzabkowski, Balogun, \& Seidl, 2007; Lounsbury, 2008; Thornton, Ocasio, \& Lounsbury, 2012). The presence and recurrence of such organizational practices can be analyzed through the institutional logics concept. Institutional logics are cognitive frameworks historically constituted, which drive and constrain the organizational actors' behavior (Thornton et al., 2012).

Taking as an example the case of Arthur Andersen, the introduction of a corporate logic had silenced the former professional (or fiduciary) logic. The prevalence of such logic seems to have led the members of the audit firm to accept inadequate practices, which eventually led to their guilty verdict (Palmer, 2017; Thornton et al., 2012). In the case of the Courts of Accounts, previous studies indicate the simultaneous existence of two institutional logics, the technical-professional logic and the elite-patrimonial logic (Lino, 2019). As the technical-professional logic prioritizes bureaucratic impersonality and the common good, conversely, the elite-patrimonial logic emerges and sustains the bargains among private-benefit oriented groups. 
The extant literature focused on organizational wrongdoing determinants. This may help to explain the dearth of research on how and why such practices are maintained over time (Palmer et al., 2016). Our analysis suggests that organizational wrongdoing is not only prompted and sustained by the leaders' characteristics or by how formal hierarchical lines distribute power, but mainly due to the institutional logics composing the institutional environment.

At the Courts of Accounts, the elite-patrimonial institutional logic is the one often associated with organizational wrongdoing (Lino, 2019). An institutional logic does not only guide the actors' behavior in charge of these organizations, as they exert power affecting the processes design and practices routinization (Battilana, 2006; Zald \& Lounsbury, 2010). At the upper layer of the Courts of Accounts, the Magistrates are powerful actors holding broad decision rights over resource allocation. Following hierarchical lines, from the leading senior auditors, audit teams' supervisors coordinate the subordinated tenured auditors holding less discretion and power (Lino, 2019; Moreira \& Vieira, 2003). The greater the relative power of a set of actors in command positions, the greater propensity of the organization to be oriented by the institutional logic supported by that group (Besharov \& Smith, 2014).

Powerful actors may control or mitigate the chances of the competing institutional logics to succeed. They deliberately and strategically design elements of the organizational structure for their benefit (Battilana, 2006; Lawrence \& Suddaby, 2006), counting on the maneuvering they have of relational and material resources (Lawrence, 2008). Therefore, the maintenance of an institutional logic preferred by powerful actors is linked to the imbalance of power in comparison to those who support (and are guided by) the conflicting logics (Spence \& Carter, 2014). The analyzed case presents that the powerful Magistrates support the elite-patrimonial logic embracing all types of organizational wrongdoing.

The empirical findings and discussion contribute to the understanding of the occurrence and support of organizational wrongdoing at the Courts of Accounts, and analyzes the strategies deployed by powerful actors to maintain organizational wrongdoing. The "powerful actors" here are those with more access to relational and material resources. We followed a qualitative approach to analyze the recent corruption events surrounding the Court of Accounts of the State of Rio de Janeiro (RJ CoA), based on interviews and document analysis. We select the case according to the methodology perspective offered by Greve et al. (2010) in which the organization's wrongdoing is an empirical event according to social-control agents rather than a researcher evaluative judgment. In this case study, the wrongdoing was revealed in 2017 by the Federal Public Prosecutor Office and the Federal Police implicating the Courts' Magistrates. According to the Federal Public Prosecutors, the Magistrates received kickbacks to relax inspections on several contracts signed between the State Government and private contractors.

Our findings pointed out that the power dynamics were crucial to mitigate the technicalprofessional institutional logic. Such power dynamics are formal but also informal, exerted by actors guided by the elite-patrimonial logic to enhance private gains. Such private benefits often violate the law, but are always considered immoral (Ashforth \& Lange, 2016).

\section{HIERARCHY AND POWER: THE SOURCE OF ORGANIZATIONAL WRONGDOING}

Organizational wrongdoing is the individual behavior within an organization that goes beyond the imaginary line that separates the right from the wrong, being such transgression assessed by a socialcontrol agent (Greve et al., 2010). The social-control agent is a stakeholder (individual or organization) 
enrolled by the community to impose sanctions on its behalf (Greve et al., 2010). Such an imaginary line and the social-control agent's enforcement are employed by the institutions in place, including laws, professional codes and the widely accepted ethical principles (Palmer, 2017). Put differently, organizational wrongdoing is not legitimate according to the evaluation of a social-control agent that would act as a source of legitimacy (Deephouse \& Suchmann, 2008).

This illegitimate behavior may involve self-interested violation of the law or the immoral principles that purposefully (or not) harm others (Ashforth \& Lange, 2016; Greve et al., 2010). Therefore, organizational wrongdoing is socially constructed, varies over time and place, and depends on social-control agent's evaluation (Palmer, 2017). For example, at the beginning of the First Industrial Revolution, organizational practices associated with child labor and job shifts over 10 hours of daily work were appropriate. Nowadays, most contemporary societies have a different understanding.

Previous studies indicate that organizational wrongdoing, in general, starts at the top of the organizational hierarchy (Ashforth \& Anand, 2003; Palmer, 2017). As hierarchy lines bring formal authority (which is a form of power distribution) less powerful actors at the bottom are compelled by their superiors to silence and even to participate in wrongdoing (Ashforth \& Anand, 2003; Palmer, 2008). Despite the hierarchy, the role and status of top officers may influence their subordinates (Phillips, Lawrence, \& Hardy, 2004). For instance, the high-ranked executives engaged in wrongdoing inadvertently authorize such practices at lower hierarchical levels (Ashforth \& Anand, 2003). The typical social ties among elite groups also induce powerful actors to create opportunities for misconduct (Palmer, 2017). Therefore, although authority lines and social ties would reduce coordination problems and facilitate economic exchanges, they may also make wrongdoing to be dispersed in routines within the organizations (Palmer, 2013).

Power is central to organizational wrongdoing. Power is a relational phenomenon in which an actor or group (with higher power) can change the beliefs and behaviors of other actors (with less power). Such an action is manifested in episodic or systemic ways (Palmer, 2013; Lawrence, 2008). An episodic power is a discrete action by actors using influence or force (the latter is unusual in modern organizations) (Lawrence, 2008; Pfeffer, 1981). As the influence type affects the calculation of costs and benefits of an actor to perform a given action, the force uses to restricts actions to be taken (Lawrence, Winn, \& Jennings, 2001). Conversely, systemic power is impersonal, operates via routines and rules, and contributes to the organizational hierarchies' stability (Lawrence, 2008). Examples are the assignment of organizational roles, job-positions and other rules that distribute and legitimate decision-rights (Hardy \& Clegg, 1996; Lowndes \& Roberts, 2013).

Usually, powerful actors and groups within organizations are able and legitimate to design the rules and routines that are the systemic power source, and often act in such way to benefit themselves and their preferred institutional logics (Battilana, 2006; Kellogg, 2011; Lawrence et al., 2001). Institutional logics are cognitive frameworks that act as guides for actions in organizations (Thornton et al., 2012). However, rules and routines created by powerful actors often count on additional support. A set of non-elite actors (middle-managers), empowered with discretionary decision rights and influence 
power over the remaining subordinates, acts daily to maintain the ongoing power structures and the institutional logics (Lawrence, 2008; Lawrence \& Suddaby, 2006).

To some extent, such middle-managers engage in wrongdoing due to "reciprocity norms (Javor \& Jancsics, 2016; Palmer, 2008). The expectation of reciprocity guarantees favors to them. They may get allowances in addition to salaries from job-positions leading them to maintain wrongdoing on behalf of the powerful group. Such favors would also come in the form of political or cultural resources (Khan, 2012; Palmer, 2008).

Frequently, multiple institutional logics act simultaneously over an organization (Besharov \& Smith, 2014), distributed along with different organizational areas or departments (Birkholz, 2015). The multiple logics have varying degrees of compatibility and centrality to the organization. The more compatible and consistent with each other the logics are, the more they reinforce themselves. Similarly, the more central the logics are, the more valid and relevant to the organization's functioning (Besharov \& Smith, 2014). Usually, the logics preferred by powerful actors have a preponderance since they are strategically designed and supported by those actors (Zald \& Lounsbury, 2010).

Regarding the different organization departments, task specialization and responsibilities assigned to each department facilitate the emergence and maintenance of organizational wrongdoing. The actors from one department may not access all information about other parts, especially from different hierarchical layers (Ashforth \& Anand, 2003; Palmer, 2008). Furthermore, actors from one department may count on some form of protection, as industrial secrecy or strategic knowledge. As different practices are associated with different logics, departmentalization could increase the negative effect of task specialization. Consequently, various departments follow different and event incompatible institutional logic to execute their duties.

If a dominant institutional logic brings with it features allowing or favoring legal rules breaking and fragile moral foundations, it is likely to induce the emergence of organizational wrongdoing for departments under such logic (Palmer, 2017). The relative power of the actors guided by this wrongdoing - logic open opportunities to create rules and intra-organizational routines favoring the elite groups and reinforcing their preferred institutional logic.

Therefore, the powerful group will launch initiatives of systemic and episodic power to maintain organizational wrongdoing, indirectly strengthening the dominant logic and mitigating the resistance of competing institutional logics (not compatible with its practices and objectives). Their initiative can occur even if the competing logics are also central to the organization. For example, according to Thornton et al. (2012), the imbalance caused by the preponderance of market logic may be one of the roots of the misconduct that led to the global crisis of 2008. However, it lacks a discussion on maintaining inappropriate practices from an institutional perspective (Palmer et al., 2016).

\section{ORGANIZATION AND PRACTICES WITHIN THE COURTS OF ACCOUNTS}

Courts of Accounts are public sector audit organizations responsible for the external audit over public spending and service delivery by governments. Its primary duty is to issue a "Courts' report" about the annual accounts of each government under its jurisdiction (Hidalgo, Canello, \& Lima- 
de-Oliveira, 2016; Speck, 2011). In Brazil, the Supreme Audit Institution (Tribunal de Contas da União) audit the federal government, and the Regional Courts of Accounts (CoAs) oversight states and municipalities. The regional CoAs follow a Napoleonic model (Stapenhurst \& Titsworth, 2001). As they are autonomous, they hold some differences regarding their operational features, how they interpret some aspects of the legal regulations, and on the audit processes (Azevedo \& Lino, 2019; Lino \& Aquino, 2018; Nunes, Marcelino, \& Silva, 2019).

Previous literature provides evidence of organization wrongdoing within CoAs (Loureiro et al., 2009; Teixeira, 2017). CoAs are organized in two layers (an upper and a lower layer) to run four organizational roles. The lower layer comprises the audit teams (tenured auditors). The upper layer is formed by a judicial collegiate of Magistrates. The upper layer comprises the Magistrates themselves, the stand-in Magistrates (substitutes for absence or leaving periods), and the Prosecutor (representing the Prosecutor Office). The latter is in charge of ensuring the consistency and application of rule-of-the law to all audit processes (Willeman, 2016). The Magistrates are appointed by the governor and by the state assembly, following political criteria (Loureiro et al., 2009; Paiva \& Sakai, 2014), the remaining actors at the Court, mostly are selected via competitive public examinations.

The collegiate members, especially the Courts presidency, have full discretion over the organization and exert influence through the formal hierarchy over the remaining subordinates (Moreira \& Vieira, 2003). Magistrates' mandate allows them to design the internal rules and standards for the entire CoA, therefore they hold power to shape (systemically) internal practices (Lawrence, 2008). They also hold decision rights to allocate resources, including free assignment of job-positions and allowances (Moreira \& Vieira, 2003).

Previous studies suggest that at least two institutional logics permeate the Courts of Accounts. First, the technical-professional logic looks for protecting "the public interest and the efficiency of expenditures by governments following an objective and impersonal perspective" (Lino, 2019, p. 35). Second, an elite-patrimonial logic drives actor to "maximize (or maintain) political, economic or cultural gains through interpersonal bargains" (Lino, 2019, p. 35). According to Loureiro et al. (2009) and Paiva and Sakai (2014), most of the Magistrates follow the elite-patrimonial logic due to their ties with political parties. Institutional logics are distributed differently over the hierarchical line (Spence \& Carter, 2014). The members at the upper layer would follow a self-interested and immoral logic. According to Ashforth and Anand (2003), the upper layer inclination to such logic is one reason to spread of organizational wrongdoing throughout the entire organization.

Another evidence of organization wrongdoing is the named partisan voting. Azambuja, Teixeira, and Nossa (2018) discuss partisan voting by CoAs when judging the governmental accounts. The audit process usually starts at the audit teams from the lower layer, they plan and execute the audit task and deliver an opinion report with auditing findings (with red flags for potential irregularities). The Prosecutor validates the opinion report. The rapporteur, selected among the collegiate members, gets the judicial process to issue a recommendation (agreeing or not to the auditors' opinion report). At that stage, the rapporteur eventually requires additional information to audit teams as the auditees can defend themselves supported by new pieces of evidence and justifications. All data by auditee defense inspected (by audit teams), the rapporteur issues the reccomendation and remedies to the Magistrates voting (issuing the Court's report). Stand-in Magistrates only attend the voting if a minimum quorum 
is required. Even when very serious irregularities are pointed out by the audit teams, rapporteurs tied to political parties tend to neglect the indicia of irregularities and suggest the approval of municipal accounts (Azambuja et al., 2018; Hidalgo et al., 2016). Such a partisan voting can be enhanced due to the limitation of social participation regarding the Courts of Accounts (Rocha, 2017).

\section{METHODOLOGY}

This article is an in-depth or critical case study (Yin, 2009), carried out at the Rio de Janeiro State Court of Accounts (RJ CoA). We run interviews (between 2017 and 2019) and analyzed documents and newspapers content. The authors guaranteed access to the case after unfolding investigations that uncovered a corruption scandal at the organization in March 2017 - featuring a typical example of organizational wrongdoing, according to Federal Public Prosecutor Office and the Federal Police of Brazil. Therefore, it is an external valuation by social-control agents (Greve et al., 2010). Through an abductive method (Reichertz, 2014), we observed the organizational wrongdoing developed at RJ CoA was related to the elite-patrimonial logic, despite the existence of audit teams and other actors guided by a technical-professional logic. Such logics were first described by Lino (2019), as being incompatible under the auditing process of governmental accounts. The case was purposefully selected (Lavrakas, 2008), due to its characteristics (presence of organizational wrongdoing and multiple institutional logics) to identify strategies for maintaining wrongdoing in an organization with incompatible institutional logics. It is noteworthy that the results found in single cases are generalizable to the theory, but not to populations (Yin, 2009). However, complementary interviews in the field reinforce that our results from this critical case may apply to other public sector audit organizations in Brazil.

\subsection{Context of the case}

From December 2016 to March 2017, Federal Police of Brazil and the Federal Public Prosecutor Office run two investigations, named "Descontrole" and "O Quinto do Ouro" - both about corruption implicating Magistrates from the RJ CoA. They were accused of receiving kickbacks from engineering and services contracts to not interfere with bids of some constructors (G1, 2017). According to the complaint presented by the Attorney General's Office (AGO, 2018), the first payment to Magistrates occurred at the moment the CoA validated the public notice, and the following payments at the contract signature and at each invoice paid by the government. The complaint cites a criminal operation conducted by "members of the RJ CoA, with the relevant participation of people from the local state assembly and governors and mayors" (AGO, 2018, p. 18).

According to the investigations, the RJ CoA president controlled the entire irregular transactions, and all illegal payments are tied to construction contracts invoices and payments (AGO, 2018). The rendezvous and delivery of cash envelopes took place at the presidency's office at the RJ CoA, according the narrative offer by the President himself in the plea bargain (AGO, 2018).

The constructors - Andrade Gutierrez, Carioca Engenharia and Odebrecht - representatives in their plea bargain statements describe that various job-positions within the organization participated as intermediaries or operators to the corruption scheme. The criminal process initially arrested and subsequently removed all (except one) Magistrates of the RJ CoA (AGO, 2018). According to the 
investigations, a civil servant from RJ CoA collected the illegal payments directly from the constructors to deliver to the courts' President. Eventually, he provided the bribe at the magistrates' home. The job-positions mentioned as intermediaries varied depending on the President. Each Magistrate's office implicated to the corruption scheme had a loyal squire to oversee the illegal operation on behalf of the Magistrate. All of those loyal squires also implicated in the criminal investigation get allowances in Magistrates' advising teams (AGO, 2018). Only one Magistrate did not participate in the corruption scheme. According to the newspaper O Dia (2017), each Magistrates' advising teams at RJ CoA had 20 (not tenured and tenured) employees, about three of them making more than $\mathrm{R} \$ 30,000.00$ (superior to the average salary for auditors at lower layer). The AGO complaint (2018) focused just on the Magistrates, not including tenured and non-tenured civil servants' participation - so that the detailed information on the participation of other members of the organization is lacking.

It is worth mentioning that an article in Veja magazine (2008) presented evidence of an investigation in which a consulting company allegedly paid for the approval of Mayors' annual accounts, their clients. According to this evidence, the scheme beneficiated the RJ CoA president, other four Magistrates and some advisers. Therefore, the organizational wrongdoing at RJ CoA would not be new, nor related only to large contracts such as the ones highlighted by the AGO (2018), in which all government contracts above R 5 million had $1 \%$ of the amount allocated to the RJ CoA collegiate members.

Thus, the evidence suggests that part of the organizational wrongdoing would also occur in the audit of Mayors' annual accounts of municipalities from Rio de Janeiro state. As Magistrates allegedly received monetary payments to guarantee protection for mayors, it was the subject of a parliamentary inquiry commission in the State Assembly of the Rio de Janeiro (ALERJ), Resolution no. 761/2009, led by the state deputy Cidinha Campos. The deputy justified the inquiry commission stating that the consultancy firm "worked for several city halls interested in approving their governmental accounts at the Court and, for that, they did not need lawyers. It was enough to buy the Magistrates [with bribes]" (quoted in the process). Such evidence corroborates the Veja magazine article (2008). Finally, due to lack of evidence, the Superior Court of Justice (SCJ) did not condemn the Magistrates in 2016 and did not accept the Federal Public Prosecutor Office argument for passive corruption involving them.

Despite the removal of RJ CoA's Magistrates due to predominantly kickbacks, the focus of this article is on the protection of political allies in the audit of governmental accounts - a form of organizational wrongdoing occurring and corroborated by evidence above.

\subsection{Data collection}

Our data collection relies on interviews and documents. As this critical case at hand had massive coverage by media, newspapers were an essential source of analysis.

To access the case was not trivial due to the context of corruption investigation recently concluded in the organization. The access was granted based on trust with the interviewees. The first and necessary step was to obtain formal permission from the interim President of RJ CoA at the time (that replaced the former arrested President). Permission was granted by the interim President based on a term of intentions by the authors on December 5, 2017. In summary, the term requested interviews with the interim President, the leading senior auditor and with the training department ('School of Accounts') 
director. The first interview took place with the interim President, followed by the authorization for new rounds of interviews with various actors through snowball sampling (Rapley, 2014). Despite the probable bias of snowball sampling, it is the most recommended for studies of this nature (Javor \& Jancsics, 2016). With the support of the Presidency, the authors interviewed tenured auditors, Magistrates, stand-in Magistrates and former members of the Public Prosecutor's Office.

In total, seven tenured auditors and three stand-in Magistrates or Magistrates and one former Prosecutor were interviewed. The recommended interviewees were contacted by email or by telephone (snowball sampling). Some of the interviewees participated more than once, we had 16 interviews of 54 minutes on average. The interviews were carried out remotely (phone, Skype or WhatsApp) according to the interviewee's preferences about schedule and media. For instance, some interviewees required to attend the interview out of working hours, while others participated from their desk at RJ CoA headquarter.

The interviews were recorded and literally transcribed, always in a timely manner, to keep the data collection pace and increase the quality of probing questions usage in the next interviews (Biernacki \& Waldorf, 1981; Kowal \& O'Connell, 2014). Such a procedure helped to increase the pace of data saturation (Schreier, 2014). The literal transcription sought to guarantee the reliability of the use of collected narratives (Christians, 2000).

Given the sensitive topic, the ethical risks and preservation of the respondent was our central concern. Due to the infeasibility to get a paper signing of an 'informed consent form', we adopted the following procedures for the reduction of ethical risks, following Christians (2000). First, voluntary participation was guaranteed and reiterated (Christians, 2000). The interviewees were reminded that they might get into details about what they felt comfortable. Second, all recording files were encrypted without interviewee identification. Third, we carried out the member checking of our findings (Cho \& Trent, 2006). The respondents did not suggest changes in the narrative developed by the authors. Just one comment required to remove from the Table their educational background to preserve anonymity. It was immediately accepted by the authors. Fourth, the text use quotations by the interviewees to illustrate the findings however, such quotes remain anonymous (randomly assigning a label from $\mathrm{A}$ to $\mathrm{K}$ to each respondent) as a way of preserving them from retaliation and letting them comfortable to address the topic.

We applied two semi-structured protocols to capture the relevant practices for maintaining organizational wrongdoing for the analyzed case. The same practices were compared with the institutional logic in force in the CoAs detailed in the relevant literature. The protocol also counted on the extensive use of probing questions to address emerging issues (Eisenhardt, 1989).

The first protocol for non-tenured auditors considers an elite interviewing technique (Leech, 2002; Richards, 1996) focus on the interactions of the Magistrates to audit processes related to the governmental accounts. We observed how the practices of the Magistrates could impact the audit work, segregating the protocol application into two moments in time: (i) the present moment and (ii) prior to the corruption scandal that came into public. Additionally, we asked about the governmental accounts audit process (flow of activities) of the municipalities. Finally, we asked about their social background, career trajectory and educational track (triangulated with public documents). 
The second protocol applied to tenured auditors addressed the key opportunities and challenges they have (or not) to play their role. We also covered their activities and daily routine, and their career trajectory and educational track. Finally, they were asked to detail the main changes in the RJ CoA after the corruption scandal being uncovered and the removal of the incumbent Magistrates.

Complementarily, we considered newspapers to triangulate the practices associated to wrongdoing raised during the interviews with what was revealed by the media (Flick, 2007). We select the period from 1970 to 2018 to analyzed newspapers for three reasons. First, the context of the case shows that organizational wrongdoing persisted for years and the removed Magistrates started their careers in the late 1960s. Second, there is evidence of an elite-patrimonial logic associated with wrongdoing - existing in the Courts of Accounts since before the enactment of the Brazilian Federal Constitution (CF, 1988). More than 100 newspapers articles published in the State of Rio de Janeiro during that period were accessed on online repositories of the National Library, by keywords as "Tribunal de Contas", "Tribunal de Contas do Estado do Rio de Janeiro" and "TCE-RJ".

We also searched for the names of the removed Magistrates in 2017, as well the Magistrates and stand-in Magistrates who replaced them. The sampling of analyzed news followed the random technique suggested by Bauer (2007). Internal documents of the RJ CoA were also analyzed, such as the internal regulations, the organization chart, the organic law, the minutes of meetings, audit manuals and some auditing processes (of governmental accounts) selected at random or suggested by the interviewees.

The set of data and evidence gathered is part of a broader research project maintained by the authors. Each article that uses this data has its own research objectives, such as, for example, analyzing the forms of institutional work used by the actors at RJ CoA to restore the balance of power in the Court, considering the scandal as an exogenous shock. In another article, the authors use evidence from the case to analyze how political party interference in the internal dynamics of the Courts threatens its legitimacy supporting corruption networks along these audit organizations.

\subsection{Data analysis procedure}

A content analysis was performed to reduce and converge patterns in the collected material (Schreier, 2014). We adopted a neopositivist perspective of analyzing the interviews (Roulston, 2014) in which the interviewees' perception is taken as factual. Therefore, multiple data sources (i.e., the various interviewees) are used to validate the reported points of view, to the extent that new information is not added by new informants, achieving data saturation (Schreier, 2014).

During the interviews, the themes that emerged were discussed in meetings between the authors, generating what is called preliminary open coding (Cornish, Gillespie, \& Zittoun, 2014). The main themes were organized in an electronic spreadsheet (Miles \& Huberman, 1994). In addition, the authors also compared the emerging categories with the relevant literature. Due to the research objective, the focus of the codification process fell on the "six Cs" - causes, contexts, contingencies, consequences, covariance and conditions (Thornberg \& Charmaz, 2014). This 
continuous interaction between the relevant literature and data obtained in the case, typical of abductive studies, made it possible to refine the categories of analysis that emerged (Eisenhardt \& Graebner, 2007).

\section{ORGANIZATIONAL WRONGDOING AT RIO DE JANEIRO'S COURT OF ACCOUNTS: FINDINGS AND DISCUSSIONS}

One of the primary duties of the regional Courts of Accounts is to audit the government accounts of mayors and governors (the Tribunal de Contas da União oversees the Presidency's accounts at the federal level) (Hidalgo et al., 2016). Based on audit opinions prepared by audit teams, Magistrates judges the accounts' compliance with the law and enact a Courts' report (recommending the approval or not the mayors' or governors' accounts). The Magistrates' judgment would consider whether the budgetary and financial statements of the municipality or state are compliant with the public finance regulation. However, the following evidence indicates that the audit-judicial process usually does not strictly follow the rule-of-law but is oriented to self-interest. Other studies previously observed such a trend (e.g. Azambuja et al., 2018; Loureiro, Teixeira, \& Prado, 2008; Teixeira, 2017), which can ultimately harm society as the CoA no longer exercise oversight over public resources.

We identified different types of wrongdoing that occurred at the RJ CoA. Some of them are what we classified as embryonic wrongdoing. We defined the embryonic wrongdoing as the violation of the primary role of the organization. In the analyzed case, the embryonic wrongdoing is partisan voting by the Magistrates oriented by undue political influence from their political allies or other agents acting on behalf of the auditees, to achieve private gains. The actors within the organization deploy a series of illegitimate practices to implement, sustains or hide the embryonic wrongdoing. We named them supportive wrongdoing, and such enabling practices are constantly up-to-dated and expanded over time, depending on the unfolding context of action. For the case of RJ CoA, we compiled seven supportive wrongdoing (Box 1).

According to the interviews, wrongdoing concerning the mayors' governmental accounts process within the Court of Accounts can occur in at least two different ways. First, explicitly, using episodic power - as anticipated in the literature section - the Magistrates exert partisan voting and diverge from the auditor's opinion. Magistrates do not accept as valid or relevant the irregularities identified by the auditor. Such practice ('reversão de pareceres" in Portuguese) is explored by the Brazillian current literature on CoA (e.g. Azambuja et al., 2018; Hidalgo et al., 2016). However, less explored in the literature is how Magistrates support such practice inside the organization, by the use of systemic power. Magistrates enact and support rules initiatives to control resources and constrain audit teams' behavior, which, et the end, may mitigate the quality of audit findings and reducing the likelihood to detect irregularities. Furthermore, rules of systemic power can interact and reinforce the episodic power of Magistrates. 


\begin{tabular}{|c|c|c|}
\hline Wrongdoing & Episodic power & Systemic power \\
\hline Neglecting audit findings & $\begin{array}{l}\text { Magistrates diverge from auditors } \\
\text { without a reasonable justification. }\end{array}$ & - \\
\hline Denying access to audit records & $\begin{array}{l}\text { Magistrates impede publicization of } \\
\text { audit opinions. }\end{array}$ & - \\
\hline $\begin{array}{l}\text { Not voting audit opinion with serious } \\
\text { irregularities }\end{array}$ & $\begin{array}{l}\text { Magistrates compose the voting } \\
\text { agenda selectively and hide } \\
\text { processes. }\end{array}$ & - \\
\hline Reciprocity (exchange of favors) & $\begin{array}{c}\text { Magistrates allocate allowances } \\
\text { and not tenured job positions to get } \\
\text { loyalty. }\end{array}$ & - \\
\hline Reduction of audit on-site working hours & Magistrate design the rules. & $\begin{array}{l}\text { Rules induce allocation of working } \\
\text { audit hours to irrelevant tasks. }\end{array}$ \\
\hline Influence on the audit planning & $\begin{array}{c}\text { Magistrates and leading senior } \\
\text { auditor influence on audit object, } \\
\text { scope and and how auditors should } \\
\text { proceed. }\end{array}$ & $\begin{array}{l}\text { The following rules support such } \\
\text { practice: (i) reciprocity rules; (ii) } \\
\text { rules of task allocation reduce audit } \\
\text { planning. }\end{array}$ \\
\hline Silencing the auditors' requests & $\begin{array}{l}\text { Magistrates decide and enforce } \\
\text { hierarchical organizational lines. }\end{array}$ & $\begin{array}{c}\text { Hierarchy entrenches the Magistrates } \\
\text { and makes them unreachable to } \\
\text { auditors' requests. }\end{array}$ \\
\hline
\end{tabular}

Source: Elaborated by the authors.

Denying access to audit records is a relevant baseline to partisan voting, as it impedes the scrutiny by external stakeholders on why Magistrates neglected the auditors' opinion in one specific case. Magistrates use their episodic power to refuse such access. Those processes were never public, not even under consultation. Before the corruption scandal surfaced, auditors' opinion reports full content was not released nor as physical documents nor electronically.

"Before the removal of the Magistrates, the audit opinion reports were not fully disclosed. It was just a summary of the report. There were also secret sessions [meetings] of Magistrates" (Interviewee A).

In such a context, it is not possible to exercise social control over the audit jobs and associated findings to verify the divergences between the auditors' opinion and the collegiate' voting. Divergences between Magistrates' and auditor's opinions are legitimate occurrences when justified by legal, accounting, or financial basis, however, in the CoA divergences were oriented by other logic. According 
to an interview (A), the Magistrates voted in disagreement with the audit teams "according to their own conscience", baseless and without any further justification.

As a consequence of the lack of transparency due to inaccessible audit records, Magistrates guided by an elite-patrimonial institutional logic can revert the audit findings, and they frequently do (Table 1). The next table shows the divergence between Magistrates and audit teams (before the corruption scandal came to the public; the accounts up to 2015 were judged by the removed magistrates). As illustrated by an interviewee:

"There was a specific decision on the engineering work at the Maracanã stadium [for the 2014 World Cup] in which there occurred an inexplicable divergence [between Magistrates' and audit teams' positions]. Because the Rapporteur could take advantage of the Court's opaqueness on that occasion, he reversed the recommendation regarding the auditors' [negative] opinion." (Interviewee E).

The partisan voting strategy is used only as a last resort, due to the political and legitimacy costs as it is easily observed. At least it will be easy to follow if the auditors' opinions could be accessed or mentioned with more details in the Courts' reports issued by the collegiate. In such a case, it would be possible for any interested party to compare an unjustified divergence.

TABLE 1
DIVERGENCE ON OPINIONS BY AUDIT TEAMS, RAPPORTEUR AND FINAL VOTE BY THE COLLEGIATE AT RJ COA

\begin{tabular}{|c|c|c|c|c|c|}
\hline & $2011[\%]$ & $2012^{1}[\%]$ & $2013[\%]$ & $2014[\%]$ & $2015[\%]$ \\
\hline Auditors' opinion - pro approval & 65 & 40 & 75 & 60 & 72 \\
\hline Collegiate followed auditors' opinion & 65 [100] & 40 [100] & 75 [100] & 60 [100] & $72[100]$ \\
\hline Auditors' opinion - pro rejection & 26 & 51 & 16 & 31 & 19 \\
\hline Rapporteur did not follow auditors' opinion & 18 [69] & 20 [39] & $12[75]$ & 19 [61] & $9[47]$ \\
\hline Collegiate did not follow auditors' opinion & $4[15]$ & $5[10]$ & $3[19]$ & 9 [29] & $2[11]$ \\
\hline Collegiate followed auditors' opinion & $4[15]$ & $26[51]$ & $1[6]$ & $3[10]$ & $8[42]$ \\
\hline
\end{tabular}

${ }^{1}$ For electoral years, as municipal elections in 2012, the auditor's opinions follow specific requirements from Fiscal Responsibility Law (FRL) on budgetary expenditures.

Source: Elaborated by the authors

According to the president of the RJ CoA as the scandal was emerging the "collegiate was concerned with not violating the analysis of the audit teams" (PGR, 2018, p. 85). Therefore, the audit findings were postponed by decision of the Magistrates, rather than directly neglected at the collegiate voting. Complementary wrongdoing at $\mathrm{RJ} \mathrm{CoA}$ is the judicial process delaying (letting the audit opinion and the judicial process rest on the presidency shelf), for instance, requesting in the plenary session for 
more time to analyze the case ('pedido de vista'). This and other initiatives are employed to postpone voting until a favorable moment to be voted by the collegiate, favoring the auditee, depending on the ability to influence the agenda (Pfeffer, 1981).

"[Another thing] that the Magistrates usually done was to postpone the process" (Interviewee E).

"The Rio de Janeiro Court of Accounts held 54 archived processes, rigorously hidden at the president's room who was in charge of the corruption scheme. Whey those processes are not allowed to come to the daylight, even they could not be voted, as people would realize what was going on. Why they hide? They were running their business" (Interviewee $\mathrm{K}$ ).

Postponements or delays of judicial processes are also exerted by advisers or other middle managers at the intermediate zone as episodic power. For example, according to the interviewees, before the corruption scandal come public, a CoA president's relative occupied a job-position where all judicial processes come together. So, he accessed classified information and, according to interview with respondent A, "he passed on the information to the municipality, [he] sold the information and charged for it". However, eventually was not possible to protect the implicated municipality. According the same respondent, if the advisors identified "something that could compromise [the Mayors], or that he had no way of not attending, he delayed the process to the limit".

The CoA president's relative also exposes the wrongdoing of improper assignment of job-positions with allowances. Such assigned positions owe favors and operate according to the norm of reciprocity (Palmer, 2008). Part of these favors is to assist in the protection of allied municipalities, either by providing privileged information, or by acting directly in the auditing process, creating justifications for not rejecting the governmental accounts. In addition, according to the interviewees' report, the protection offered by the Magistrates to Mayors granted job-positions to them in City Halls, which will be occupied by individuals from Magistrates' network. A list of respondents (for instance, A, $\mathrm{E}, \mathrm{K})$ mentions that the higher the assigned job-positions at CoA the lower the incentive for those following the technical-professional logic to manifest themselves contrary to the status quo.

The elite-patrimonial logic is present at different organizational levels and also guides tenured auditors' behavior, as some of them look for monetary gains from job-positions with allowances. Thus, Magistrates are not "solely" who engenders the wrongdoing, as the logic is disseminated over the organization. It is noteworthy that, given that tenured public servants also operate wrongdoing, technocracy would not be the solution to the problem. According to respondent $\mathrm{H}$, another form of episodic power used at the time to maintain wrongdoing is the use of force, such as threats to relocate the auditor to less preferable location or threats of dismissal from the job-position with allowances.

The balance between institutional logics fluctuates over time according to the power of groups in that organization (Dunn \& Jones, 2010). For the analyzed case, similar to Spence and Carter (2014), the strategies come from the dominant elite-patrimonial at the upper layer. Still, the centrality of institutional logic changes over the workflow of the audit and judicial process. The audit process initiate based on a purely technical-professional logic but ends at its judicial stage under an elitepatrimonial logic. Therefore, it appears a gray area as the audit flow converges to a judicial process when actors are likely to mix the two logics. 
Collegiate members (especially the President) looking to preserve the magistrates' organizational power and the ongoing wrongdoing, employ the job-positions with allowances to capture tenured auditors at the bottom of the hierarchy. The transfer of monetary incentives to auditors require their reciprocity under the elite-patrimonial logic. Therefore, the Magistrates' preferred logic spreads down to the operational layer up to the very beginning of the audit workflow, normalizing and routinizing organizational wrongdoing - what is called "culture of corruption" by one of the interviewees.

"We know there is a culture of corruption and it is challenging to change. The tenured civil servants also are enrolled to such, don't they? By consenting or participating... So, such a thing that unfortunately happens, this culture must be interrupted" (Interviewee A).

"Sometimes it occurs that our supervisor [leading senior auditors] knows that our audit opinion will claim for an adverse opinion [bringing critical red flags]. Imagine that you are at the coffee machine and describe to someone about a specific audit finding. Sooner or later, the supervisor will know about that, and if it is from their interest, he will act. For example, I know cases where the auditor leaves the audit notebook on the desk after his worktime to continue working in the morning. Then the supervisor catches the notebook and the documents to reallocate to another auditor [willing to report a clean opinion] or issue an opinion by himself the next morning" (Interviewee $\mathrm{H}$ ).

In addition to episodic power, Magistrates, and the aligned advisors and leading auditors, also sustain organizational wrongdoing by systemic power. The rules shape routines affect audit teams' efforts and reduce their ability to identify audit findings. Some examples are work overload, influence on audit planning, lack of IT support and distance from powerful actors to audit teams. According to respondent $\mathrm{C}$, the overload of audit tasks in some departments was so great that converted the audit work in something "humanly impossible".

For auditing, the literature highlights the relevance of autonomy and independence to select audit objects, according to risk, materiality, relevance, and opportunity criteria. For the analyzed period, the systemic rules imposed by the Magistrates reinforced to allocate working hours to clerical audit functions. Such functions are not considered essential by the auditors. Several respondents (including C, D, E, H) reported that all paper documents received by the Court of Accounts, from external stakeholders, should be analyzed by audit teams. Such a volume of information and senseless analysis reduces the workable time for on-site auditing and also accumulation of processes to be analyzed.

"It [the auditors' independence to select audit objects] was not a culture here. Due to compulsory accountability, each government legal act was reported by mayors and governor, the documents from one signed contract, the term itself, the call for bidding, were sent to the Court. There was an informal rule, very diffused, in which every document received by the Court should be analyzed first. So, considering the number of processes reaching the Court was huge, it was impossible to deal with them! We did not get all in loco audit done, the best way to find irregularities... as we lost our time checking papers. [...] You put your time on that, but you did not decide or asked for that information" (Interviewee E). 
According to another interviewee:

"At the external control division, we had about 500 tenured auditors, $82 \%$ of them allocated to legal compliance checking. When a municipality sends a contract, PPP proposal, and a consortium proposal, we analyzed such documents based on paper documents. We get millions of processes a year to do this legal compliance check, do you know? We realized that, often, when we verify formal compliance, it was ok, but when we checked the implemented processes, we often found many irregularities. For instance, the construction contracts: the public work was not executed; the contract was not respected, there was no minimal quality parameter in place. So, we legitimated the process overseeing paper documents, but in loco nothing was being properly executed. We dedicated more than $80 \%$ of four working hours with no contribution to the society" (Interviewee G).

While the tenured auditors remain running on legal compliance on paper documents, they were not able to go to more effective audit jobs and strategies, incurring a waste of working hours. Additionally, due to the distance between the collegiate members and the audit teams, as they could not complaint or ask for changes, the practices remained. One respondent said that was not easy or desirable to argue Magistrates, for instance, presenting evidence on the wasting time to such legal compliance:

"Many attempts... Yes, we also suggested changing the audit focus, start to focus on contracts above a minimal value, to avoid allocating time to tiny contracts. We analyzed every contract, for instance, an $R \$ 800$ contracts [150USD\$]. You can imagine the control cost of an auditor to run legal compliance of a tiny contract like that. It is a higher cost to society, and we were not able to change" (Interviewee G).

When asked if they consider feasible to discuss or just present to the Magistrates the advantages supported by the audit teams' technical studies, the respondent argued based on the presence of episodic power mechanisms. The studies proposed to replace remote auditing by on-site auditing, increasing the chances for irregularities detection.

"No, our studies were sent and received [by the magistrates]. But none of them were accepted, the studies also stopped at the Presidency. [...] The Presidency should follow the internal regulation and let the collegiate vote the study. But it does not include the study to the voting agenda" (Interviewee G).

The rules keeping distance between Magistrates and tenured auditors decrease the negotiation and understanding of actors with different orientations and perspectives. The logic preferred by the powerful actors still being reinforced and the conflicting institutional logic is constrained by the formal rules. Such reinforcement ultimately leads to the maintenance of the power structures and practices associated with organizational wrongdoing. 
The already mentioned remote auditing based on legal compliance of paper documents is enhanced by the absence of useful automated systems to assist audit work. Respondents also explained that the auditors needed to use spreadsheets with outdated data to plan the audit work, as there was no timely collection of the new raw data. It was also reported (respondent D) that the audit teams and the ICT department do not have a supportive collaboration, the audit teams' demands did not echo into the design of ICT functionalities. One of the interviewees suggested that the ICT department did not achieve the expected results due to human resources constraints.

"The director of ICT department, currently, is not connected to the external control division, but directly tied to the Presidency. In recent past, the job-positions at the ICT department were used to allocate relatives and friends... There were many senior positions at ICT Division that do not work to the main department delivery, [...] I have a colleague, he said to me, it was widespread to see somebody this week and a completely different person next week working at that division. It was a generalized mess" (Interviewee E).

In summary, the evidence suggests that the power relations at the RJ CoA were fundamental to the maintenance of wrongdoing over the years. It was also observed that the maintenance of the organizational wrongdoing was dependent, in large, on the relative power associated with the actors guided by the elite-patrimonial logic (which is characterized by political bargains aiming at the private benefit).

Such evidence led us to consider the probable causes of the subversion of the hierarchical power structure rather than operating as ideally designed to increase coordination and facilitate internal process flow. Also, to recognize that the supportive wrongdoings are tactics employed by powerful actors to support the ultimate goal of the embryonic wrongdoing.

Our findings suggest that future studies should consider that the organizational wrongdoing is maintained precisely by the dominant institutional logic, spread down to many departments of the organization. The institutional logic that embraces and is supported by the powerful actors induces practices that can transgress the law or prove to be immoral. In such cases, organizational wrongdoing is more likely to become part of the organization's "DNA", spreading across different departments to become used for different purposes. To this end, powerful actors deploy supportive wrongdoing tactics to maintain the preponderance of their preferred logic. For the analyzed case, notice some relevant aspects:

1) The Magistrates' refusal to enhance transparency at the audit process prevents the access of external sources of legitimacy to the organizational routines, at the same time that it reduces the information about the practices in the intraorganizational environment. Thus, actors (subordinate or not) guided by an incompatible institutional logic are unable to access informational resources to hamper current practices.

2) Magistrates as powerful actors, design formal rules allowing and extending norms of reciprocity (Palmer, 2008) with subordinate employees. The reciprocity of these subordinates (non-elite actors) aggregates support to the Magistrates' institutional logic all over in different departments, institutionalizing organizational wrongdoing. 
3) In addition, Magistrates, as powerful actors, reduce the centrality of incompatible logics (guided by moral and legal actions), reducing the chance to the concurrent logic proliferate. Doing so, they reinforce the persistence and expansion of organizational wrongdoing practices.

4) There are "levels" of wrongdoings, in which several supportive wrongdoings are designed and put in place by actors interested in achieving the objectives related to embryonic wrongdoings.

\section{CONCLUSION}

The analysis of the case of RJ CoA shows that organizational wrongdoing is perpetuated through strategies adopted by powerful actors, favored by the elite-patrimonial institutional logic (Lino, 2019). A group of agents tied to the network of influence of the Magistrates, as advisors and leading senior auditor, aiming to perpetuate organizational wrongdoing has induced and supported the internal accommodation of divergent or incompatible institutional logics.

Such practices arise and occur in organizational processes, intertwined in routines and structures of positions and power relations distributed throughout the organization. The practices were continuously replicated with the support of other non-elite actors, based on the norm of reciprocity. Within the elite-patrimonial logic, the strategies included the use of refusal to open audit opinions to public, rules of reciprocity (exchange of favors) and, finally, the reduction of the centrality of concurring institutional logics (preserving the dominance of the patrimonial one). The Magistrates acted to legitimize and build the systemic norms, while the advisors and leading senior auditors (in a job-positions with allowances), who owed reciprocity, actively protected the maintenance of wrongdoing.

The results contribute in three ways:

1) They add to the literature on wrongdoing the influence of predominant institutional logics, given the effect of the dominant logic operating in the actions of Magistrates.

2) Indicate that the imbalance between logics can contribute to organizational wrongdoing, if powerful actors can support the logic favorable to wrongdoing.

3) Finally, it offers to the literature on audit organizations in Latin American countries an explanation for the political influence on organizational performance.

Regarding the last contribution, the focus of the national and international audit literature has segregated the analysis of practices and organizational design. This article consolidates previous studies and points out that such practices are diverse despite having a similar objective. The embryonic wrongdoing aim to deliver a protection to mayor and governors, ends up unfolding in a set of supportive wrongdoings, all of them supported by the elite-patrimonial logic. Considering a broader perspective, the findings highlight that one of the only mechanisms of rebalancing between conflicting logics, which are part sine qua non given the current organizational structure of the Courts of Accounts, would be to have two logics with power balanced - developing a relation of accountability and checks and balances among them. Thus, illegitimate practices would be hampered within the organizational environment. Nowadays, the preponderance of the elite-patrimonial logic and the weakening of the technical-professional logic (as a consequence of the well-done 
RAP | Organizational wrongdoing in courts of accounts

efforts from magistrates and their supporters) reduce the chances to reduce wrongdoing within the organization. As a result, the Court of Accounts ceases to fulfill its social role and start to be socially demystified.

The authors suggest as research agenda to explore other cases of Courts of Accounts to verify whether the mentioned supportive tactics are employed. Additionally, if such a supportive wrongdoing still being deduced from embryonic wrongdoing or, how actors are holding audit practices at the lower layer out the influence of the elite-patrimonial logic. It is finally suggested additional efforts to understand why public sector auditors are not prone to actively joint to a national initiative looking for resisting to the patrimonial logic which often reign within Courts. 


\section{REFERENCES}

Arantes, V. A., Gusmão, I. B., \& Costa, M. C. (2019). Análise do relatório de guidance em empresas investigadas pela Polícia Federal: exame sob a perspectiva do gerenciamento de impressões. Revista de Contabilidade e Organizações, 13, e148176.

Ashforth, B. E., \& Anand, V. (2003). The normalization of corruption in organizations. Research in Organizational Behavior, 25, 1-52.

Ashforth, B. E., \& Lange, D. (2016). Beware of organizational saints: how a moral self-concept may foster immoral behavior. In D. Palmer, K. SmithCrowe, \& R. Greenwood (Eds.), Organizational wrongdoing: key perspectives and new directions (pp. 305-336). Cambridge, England: Cambridge University Press.

Azambuja, P. A., Teixeira, A., \& Nossa, S. N. (2018). Aprovação de contas municipais com irregularidades gravíssimas: quando a auditoria técnica não é suficiente. Revista de Contabilidade e Organizações, 12, e149212.

Azevedo, R. R., \& Lino, A. F. (2018). O distanciamento entre as normas de auditoria e as práticas nos tribunais de contas. Sociedade, Contabilidade $e$ Gestão, 13(2), 9-27.

Battilana, J. (2006). Agency and institutions: the enabling role of individuals' social position. Organization, 13(5), 653-676.

Bauer, M. W. (2007). Classical Content Analysis: a review. In Eds. (Bauer, M. W.; Gaskell, G.) Qualitative Researching with text, image and sound (pp. 131-151). SAGE, London.

Besharov, M. L., \& Smith, W. K. (2014). Multiple institutional logics in organizations: explaining their varied nature and implications. Academy of Management Review, 39(3), 364-381.

Biernacki, P., \& Waldorf, D. (1981). Snowball sampling: problems and techniques of chain referral sampling. Sociological Methods \& Research, 10(2), 141-163.

Birkholz, C. (2015). Hybrid organizing under institutional complexity: insights from impact investing and social entrepreneurship (Ph.D. Thesis). University of St. Gallen, St. Gallen, Switzerland.
CBS. (2019, October 31). Uber allegedly paid $\$ 100,000$ ransom and had hackers sign NDAs after massive data breach. Retrieved from https://www. cbsnews.com/news/uber-hack-company-allegedlypaid-hackers-ransom-had-them-sign-ndas/

Cho, J., \& Trent, A. (2006). Validity in qualitative research revisited. Qualitative Research, 6(3), 319-340.

Christians, C. G. (2000). Ethics and politics in qualitative research. In N. K. Denzin, \& Y. S. Lincoln (Eds.), Handbook of qualitative research (2nd ed., pp. 133-155). Thousand Oaks, CA: SAGE.

Constituição da República Federativa do Brasil, de 5 de outubro de 1988. (1988). Brasília, DF.

Cornish, F., Gillespie, A., \& Zittoun, T. (2014). Collaborative analysis of qualitative data. In U. Flick (Ed.), The SAGE handbook of qualitative data analysis (pp. 79-93). Thousand Oaks, CA: SAGE.

Deephouse, D. L., \& Suchman, M. (2008). Legitimacy in organizational institutionalism. In R. Greenwood, C. Oliver, K. Sahlin, \& R. Suddaby. (Eds.), The SAGE handbook of organizational institutionalism (pp. 4977). Thousand Oaks, CA: SAGE.

Dunn, M. B., \& Jones, C. (2010). Institutional logics and institutional pluralism: the contestation of care and science logics in medical education, 1967-2005. Administrative Science Quarterly, 55, 114-149.

Eisenhardt, K. M. (1989). Building theories from case study research. The Academy of Management Review, 14(4), 532-550.

Eisenhardt, K. M., \& Graebner, M. E. (2007). Theory building from cases: opportunities and challenges. Academy of Management Journal, 50(1), 25-32.

Flick, U. (2007). The SAGE qualitative research kit. Designing qualitative research. Thousand Oaks, CA: SAGE.

G1. (2017, March 29). Operação Quinto do Ouro nasceu de delações. Retrieved from https://g1.globo. com/rio-de-janeiro/noticia/operacao-quintodo-ouro-nasceu-de-delacao-de-ex-diretor-daodebrecht.ghtml

Greve, H. R., Palmer, D., \& Pozner, J. E. (2010). Organizations gone wild: the causes, processes, and consequences of organizational wrongdoing. Academy of Management Annals, 4(1), 53-108. 
Hardy, C., \& Clegg, S. (2006). Some dare call it power. In S. R. Clegg, C. Hardy, T. B. Lawrence, \& W. R. Nord (Eds.), The SAGE handbook of organization studies (pp. 754-776). Thousand Oaks, CA: SAGE.

Hidalgo, F. D., Canello, J., \& Lima-de-Oliveira, R. (2016). Can politicians police themselves? Natural experimental evidence from Brazil's audit courts. Comparative Political Studies, 49(13), 1739-1773.

Intercept Brasil. (2019, June 9). As mensagens secretas da Lava-Jato. Retrieved from https://theintercept. $\mathrm{com} /$ series/mensagens-lava-jato/

Jarzabkowski, P., Balogun, J., \& Seidl, D. (2007). Strategizing: the challenges of a practice perspective. Human Relations, 60(1), 5-27.

Jávor, I., \& Jancsics, D. (2016). The role of power in organizational corruption: an empirical study. Administration \& Society, 48(5), pp. 527-558.

Kellogg, K. C. (2011). Hot lights and cold steel: cultural and political toolkits for practice change in surgery. Organization Science, 22, 482-502.

Khan, R. S. (2012). The sociology of elites. Annual Review of Sociology, 38, 361-377.

Kowal, S., \& O'Connell, D. C. (2014). Transcription as a crucial step of data analysis. In U. Flick (Ed.), The SAGE handbook of qualitative data analysis (pp. 64-79). Thousand Oaks, CA: SAGE.

Lavrakas, P. J. (2008). Encyclopedia of survey research methods. Thousand Oaks, CA: SAGE.

Lawrence, T. B. (2008). Power, institutions and organizations. In R. Greenwood, C. Oliver, K. Sahlin, \& R. Suddaby. (Eds.), The SAGE handbook of organizational institutionalism (pp. 170-198). Thousand Oaks, CA: SAGE.

Lawrence, T. B., \& Suddaby, R. (2006). Institutions and institutional work. In S. R. Clegg, C. Hardy, T. B. Lawrence, \& W. R. Nord (Eds.), Handbook of organization studies (2nd ed., pp. 215-254). Thousand Oaks, CA: SAGE.

Lawrence, T. B., Winn, M. I., \& Jennings, P D. (2001). The temporal dynamics of institutionalization. Academy of Management Review, 26(4), 624-644.

Leech, B. L. (2002). Asking questions: techniques for semi-structured interviews. Political Science and Politics, 35(4), 665-668.
Lino, A. F. (2019). As lógicas conflitantes no tribunal de contas e o enfraquecimento de sua relevância social (Doctoral Dissertation). Universidade de São Paulo, Ribeirão Preto, SP.

Lino, A. F., \& Aquino, A. C. B. (2018). The diversity of the Brazilian regional audit courts on government auditing. Revista Contabilidade \& Finanças, 29(76), 26-40.

Lounsbury, M. (2008). Institutional rationality and practice variation: new directions in the institutional analysis of practice. Accounting, Organizations and Society, 33(4-5), 349-361.

Loureiro, M. R., Teixeira, M. A. C., \& Prado, O. (2008). Construção de instituições democráticas no Brasil contemporâneo: transparência das contas públicas. Organizações \&Sociedade, 15(47), 107-119.

Loureiro, M. R., Teixeira, M. A. C., \& Moraes, T. C. (2009). Democratização e reforma do Estado: o desenvolvimento institucional dos tribunais de contas no Brasil recente. Revista de Administração Pública, 43(4), 739-772.

Lowndes, V., \& Roberts, M. (2013). Why institutions matter: the new institutionalism in political science. Basingstoke, England: Palgrave Macmillan.

Miles, M. B., \& Huberman, A. M. (1994) Qualitative data analysis: an expanded sourcebook (2nd ed). London, England: SAGE.

Moreira, E. D. A., \& Vieira, M. M. F. (2003). Estruturas de poder e instituições como determinantes da efetividade do Tribunal de Contas do Estado de Pernambuco. Organizações \& Sociedade, 10(26), 119-138.

Nunes, S. P. P., Marcelino, G. F., \& Silva, C. A. T. (2019). Os tribunais de contas na interpretação da Lei de Responsabilidade Fiscal. Revista de Contabilidade e Organizações, 13, e145151.

O Dia. (2017, April 4). Equipes de cada conselheiro do TCE custam até $R \$ 430$ mil por mês. Retrieved from https://odia.ig.com.br/_conteudo/rio-dejaneiro/2017-04-04/informe-equipes-de-cadaconselheiro-do-tce-custam-ate-r-430-mil-por-mes. html

Paiva, N., \& Sakai, J. (2014). Quem são os conselheiros dos tribunais de contas. São Paulo, SP: Transparência Brasil. 
Palmer, D. (2008). Extending the process model of collective organizational wrongdoing. Research in Organizational Behavior, 28, 107-135.

Palmer, D. (2013). Normal organizational wrongdoing: a critical analysis of theories of wrongdoing in and by organizations. Oxford, England: Oxford University Press.

Palmer, D. (2017). Institutions, institutional theory, and organizational wrongdoing. In R. Greenwood, C. Oliver, T. B. Lawrence, \& R. E. Meyer (Eds.), The SAGE handbook of organizational institutionalism (pp. 737-758). Thousand Oaks, CA: SAGE.

Palmer, D., Smith-Croweand, K., \& Greenwood, R. (2016). Organizational wrongdoing: key perspectives and new directions (pp. 203-234). Cambridge, England: Cambridge University Press.

Pfeffer, J. (1981). Power in organisations. Boston, MA: Pitman.

Phillips, N., Lawrence, T. B., \& Hardy, C. (2004). Discourse and institutions. Academy of Management Review, 29(4), 636-652.

Procuradoria Geral da República. (2018). Denúncia: Inquérito 1201/DF - Operação Quinto do Ouro. Brasília, DF: Author.

Rapley, T. (2014). Sampling strategies in qualitative research. In U. Flick (Ed.), The SAGE handbook of qualitative data analysis (pp. 49-63). Thousand Oaks, CA: SAGE.

Reichertz, J. (2014). Induction, deduction, abduction. In U. Flick (Ed.), The SAGE handbook of qualitative data analysis (pp. 123-135). Thousand Oaks, CA: SAGE.

Richards, D. (1996). Elite interviewing: approaches and pitfalls. Politics, 16(3), 199-204.

Rocha, D. G. (2017). As duas faces de Jano dos tribunais de contas brasileiros no auxílio ao exercício do controle social sobre a administração pública (Doctoral Dissertation). Fundação Getulio Vargas, São Paulo, SP.

Roulston, K. (2014). Analysing interviews. In U. Flick (Ed.), The SAGE handbook of qualitative data analysis (pp. 297-312). Thousand Oaks, CA: SAGE.

Schreier, M. (2014). Qualitative content analysis. In U. Flick (Ed.), The SAGE handbook of qualitative data analysis (pp. 170-183). Thousand Oaks, CA: SAGE.
Speck, B. W. (2011). Auditing institutions. In T. Power, \& M. Taylor (Eds.), Corruption and democracy in Brazil: the struggle for accountability (pp. 127-161). Notre Dame, IN: University of Notre Dame Press.

Spence, C., \& Carter, C. (2014). An exploration of the professional habitus in Big-4 accounting firms. Work, Employment and Society, 28, 946-962.

Stapenhurst, R., \& Titsworth, J. (2001). Features and functions of supreme audit institutions (World Bank PREM Note 59). Washington, DC: The World Bank.

Sugden, J., \& Tomlinson, A. (2017). Football, corruption and lies: revisiting 'Badfellas', the book FIFA tried to ban. London, England: Routledge.

Teixeira, M. A. (2017). Os tribunais de contas brasileiros e o controle dos controladores. In M. A. Alves, J. I. M. Brigagão, \& F. Burgos (Eds.), Por uma gestão pública democrática: 25 anos do Centro de Estudos em Administração Pública e Governo (pp. 203-218). São Paulo, SP: FGV EAESP.

Thornberg R., \& Charmaz, K. (2014). Grounded theory and theoretical coding. In U. Flick (Ed.), The SAGE handbook of qualitative data analysis (pp. 153169). Thousand Oaks, CA: SAGE.

Thornton P. H., Ocasio W., \& Lounsbury M. (2012). The institutional logics perspective: a new approach to culture, structure and process. Oxford, England: Oxford University Press.

Veja. (2008, July 2). Compraram o tribunal: documentos revelam que conselheiros do TCE do Rio de Janeiro vendiam decisões a prefeituras. Retrieved from https://veja.abril.com.br/blog/reinaldo/veja-48211-querida-comprei-um-tribunal/

Willeman, M. M. (2016). O desenho institucional dos tribunais de contas e sua vocação para a tutela da accountability democrática: perspectivas em prol do direito à boa administração pública no Brasil. Rio de Janeiro, RJ: Ed. PUC-Rio.

Yin, R. K. (2009). Case study research: design and methods (4th ed.). Thousand Oaks, CA: SAGE.

Zald, M. N., \& Lounsbury, M. (2010). The wizards of Oz: Towards an institutional approach to elites, expertise and command posts. Organization studies, 31(7), 963-996. 
RAP | Organizational wrongdoing in courts of accounts

\section{André Feliciano Lino}

https://orcid.org/0000-0003-1121-4971

$\mathrm{PhD}$ in Controllership and Accounting; Professor at the Faculty of Accounting Sciences at the Federal University of Pará (Facicon/UFPA). E-mail: aflino@ufpa.br

\section{André Carlos Busanelli de Aquino}

https://orcid.org/0000-0002-0329-410X

PhD in Accounting Sciences; Full Professor at the University of São Paulo (USP). E-mail: aaquino@usp.br 